\title{
COLABORAM NESTE NÚMERO
}

Geraldo Bastos Silva - Inspetor de Ensino Secundário. Licenciado em Pedagogia. Antigo Professor-Assistente de Administração Escolar e Educação Comparada da F.N.F. Antigo Professor Assistente da cadeira de Problemas Sociais e Econômicos do Brasil, dos Cursos do Departamento Nacional da Criança. Assistente de História e Geografia do Colégio Pedro II.

Dulcy Melgaço Filgueiras - Assistente de Administração do D.A.S.P. Cursos de Aperfeiçoamento na American University, Washington, D. C. Exerce presentemente a função de substituto do Diretor da Revista do Serviço Público.

EDSON NERY DA FONSECA - Bibliotecário diplomado pelos Cursos da Biblioteca $\mathrm{Na}$ cional. Organizador e professor do Curso de Biblioteconomia do Departamento de Documentação e Cultura da Prefeitura de Recife (1948). Bibliotecáriochefe da Universidade de Recife, organlzador, diretor e professor dos Cursos de Biblioteconomia da mesma Universidade (1949 1951). Inspetor regional do Instituto Nacional do Livro (1951). Chefe da Biblioteca Demonstrativa Castro Alves, do Instituto de Bibliografia e Documentação (1954-1955). Bibliotecário da Câmara dos Deputados desde 1954. Presidente da Associação Brasileira de Bibliotecários. Presidente da Comissão de Documentação da Associação Brasileira de Normas Técnicas (ABNT). M'embro individual da Federação Internacional de Documentação. Representante da ABNT na Comissão Brasileira de Classificação Decimal Universal. Autor das seguintes obras: "Importância da Bibliografia e da Biblioteca para os estudos históricos (Recife, Arquivo Público Estadual, 1953)"; "Dinâmica da biblioteca (Rio de Janeiro, Serviço Social de Comércio, Departamento Nacional, 1956)"; "Biblio- tecas e bibliotecários da província (Rio de Janeiro, Ministério da Educação e Cultura, Serviço de Documentação (Rio de Janeiro, Instituto Brasileiro de $\mathrm{Bi}$ bliografia e Documentação), 1959)".

Cléto de Paula Botelho - Contador do Ministério da Fazenda. Ex-chefe da Seção de Orientação e Contrôle da Contadoria Geral da República. ExMembro de uma Comissão de Apuração do I.B.G.E. Cursa, atualmente, a Faculdade de Direito da U.R.J.

Nelson Nascimento Santos - Engenheiro do Ministério da Fazenda, lotado no Serviço do Patrimônio da União. Possui trabalhos sôbre avaliações de terrenos de imóveis e nove processos de cálculo de áreas levantadas topogràficamente, publicados em doze revistas do Clube de Engenharia do Rio de Janeiro (sob os ns. $167,169,171,178,185,189,191,192$, 193, 194 e 202)

Alberto Bonfim - Assessor Técnico do D.A.S.P. Bacharel em Direito pela U.B.; Chefe da Seção de Regime Disciplinar do Serviço de Regime Jurídico da Divisão de Pessoal do D.A.S.P. Publicou os seguintes livros sôbre matéria juridica: "O Processo Administrativo", (7" edição) e "Vademecum Trabalhista".

JoAquim PImenta - Professor catedrático (aposentado) da Faculdade Nacional de Direito da Universidade do Brasil e da Faculdade de Direito da Universidade do Distrito Federal. Lecionou também na Faculdade de Direito de Recife. Exerceu diferentes cargos na Justiça do Trabalho. Autor de várias obras juridicas: "A questão social e o Catolicismo", "Cultura de Fichário" e finalmente, "Enciclopédia de Cultura (Sociologia e Ciência Correlatas)", trabalho que o autor já desenvolveu quase para o dôbro, a fim de ser feita a $2^{*}$ edição. 